\title{
Flood damping by reservoirs: proposition of a graphical parametric method
}

\author{
Estimativa do amortecimento de cheias em reservatórios: proposta de método gráfico paramétrico
}

Danilo Nogueira de Souza ${ }^{1}$, Ticiana Marinho de Carvalho Studart ${ }^{1}$, Iran Eduardo Lima Neto ${ }^{1}$ and José Nilson Beserra Campos ${ }^{1}$

${ }^{1}$ Universidade Federal de Ceará, Fortaleza, CE, Brasil

E-mails: danilomaxbr@yahoo.com.br (DNS), ticianastudart2010@gmail.com (TMCS), iran@deha.ufc.br (IELN), jnbcampos@gmail.com (JNBC)

\begin{abstract}
Flood reduction constitutes an important characteristic of surface reservoir design. Thus, to ensure that minimum safety standards are met, the Safety Dams Act was approved in 2010. Many multipurpose surface reservoirs are aging and getting out of the current technical standards. In Ceará State, Brazil, there are several dams built for many decades, with spillways sized by empirical formulae which are currently outdated. This article contributes to improve the understanding of the morphological and hydrological factors involved in the process of damping floods in reservoirs and the development of a simple application method that estimates the damping, from such factors. To do so, hydrological simulations of several scenarios representative of reservoir and hydrographic basins configurations were performed. As a result, the impact of each parameter on flood damping was determined. A graphical method was proposed in which all the morphological parameters of the basin and the reservoir were aggregated into a single dimensionless parameter - the Reservoir Damping Index $(\Phi)$. With the value of $\Phi$ calculated, it is possible to estimate the damping capacity of the reservoir. This method can be used for the design of new reservoirs or for the verification of reservoir spillways already constructed with other methodologies.
\end{abstract}

Keywords: Flood damping; Dam safety; Overtopping; Hydrological simulation; Graphical parametric method.

\section{RESUMO}

O amortecimento de cheias é uma função importante de reservatórios fluviais. Para garantir a segurança das barragens brasileiras, foi aprovada em 2010 a Lei de Segurança de Barragens. Muitos reservatórios de múltiplos usos estão envelhecidos e, possivelmente, não atentem aos atuais padrões se segurança. No Estado do Ceará, Brasil, há muitas barragens construídas há muitas décadas, com vertedores dimensionados por fórmulas empíricas, atualmente ultrapassadas. Este artigo contribui para melhorar a compreensão dos fatores morfológicos e hidrológicos intervenientes no processo do amortecimento de cheias em reservatórios e no desenvolvimento de um método de simples aplicação que estime o amortecimento, a partir de tais fatores. Para tanto, foram realizadas simulações hidrológicas de vários cenários representativos de configurações de reservatórios e de bacias hidrográficas para analisar o impacto de cada parâmetro no amortecimento. Foi proposto um método gráfico, de fácil aplicação, no qual todos os parâmetros morfológicos da bacia e do reservatório foram agregados em um único adimensional - o Índice de Amortecimento do Reservatório ( $\Phi)$. A partir de $\Phi$, é possível estimar a capacidade de amortecimento do reservatório. Tal método pode ser utilizado para o dimensionamento de novos reservatórios ou para a verificação do vertedores de reservatórios já construídos com outras metodologias.

Palavras-chave: Amortecimento de cheias; Segurança de barragens; “Galgamento”; Simulação hidrológica; Método gráfico paramétrico. 


\section{INTRODUCTION}

Dam safety has drawn increasing attention from the national media in recent years. This is because dam failures are often associated with devastating consequences, including loss of human life, especially in densely populated areas. According to Dam Safety Report 2015 published by National Water Agency (ANA), in the period covered by the report (Oct/2014 to Sep/2015), there were four accidents and five incidents with dams in Brazil (ANA, 2016).

Zhang et al. (2016) analyzed 1,065 cases of dam failure in several countries and noted that most reservoirs have capacities less than $100 \mathrm{hm}^{3}$ and more than half are less than $15 \mathrm{~m}$ high. In other words, a small earth dam with either a small reservoir capacity or a small height appears to have a relatively high probability to fail. The authors also point out that a dam is most likely to fail within its first five-year service, especially during the first year after construction.

When evaluating dam breaks occurring around the world between 1910 and 2010, one can observe the growth of the occurrence of serious and very serious accidents (WANDERLEY et al., 2016). In this context, several countries approved laws and adopted new safety standards for large dams, in recent decades.

The Safety Dams Act (Federal Law no 12,334/2010, BRASIL, 2010), a product of domestic concerns about dam safety, established the National Dam Safety Policy (PNSB) and created the National Dam Safety Information System (SNISB). Such norm, now in the process of updating by the Senate Bill PLS n 224/2016 (BRASIL, 2016), aims to ensure the observance of security standards of Brazilian dams.

It is worth pointing out the number of dams in the Northeast Brazil, because of the 'Damming Policy', inserted in the policy to combat droughts in the region (CAMPOS; STUDART, 2008). Only in the State of Ceará is estimated to exist about 30,000 dams (BRASIL, 2005; CAMPOS et al., 2016). Many of them were built more than 50 years ago, designed following appropriate criteria at that time and with data of that time and may constitute potential danger to life and property to downstream populations.

According to Wang and Zhang (2016), it is difficult to identify a distinct, single cause for a dam failure. Often, several causes are involved in a failure and these causes are interrelated with each other. However, the authors identify 'overtopping' as a primarily responsible for failures of dams, arriving alone, more than $30 \%$ of all failures.

Only in 2004, it is estimated that more than 300 dams of various sizes and types have failed in Brazil; most due to hydrological extreme events occurred that year (BRASIL, 2005).

Reservoirs play a determining role in flood peak damping, mitigating the adverse effects downriver from these structures. The rupture of the dam by overtopping results from the insufficiency of spillway capacity.

This paper contributes to a better understanding of morphological and hydrological factors involved in flood peak damping in reservoirs. It also innovates by developing a graphical method for its estimation expeditiously. It is expected to add another valuable tool for dam safety in hydrological perspective.

\section{THE FLOOD DAMPING PROCESS}

The hydrograph of a flood entering a reservoir changes in shape as is emerging out from the reservoir. This is due to volume of water stored in reservoir temporarily. The peak of the hydrograph will be reduced, the time to peak will be delayed and base of the hydrograph will be increased. It has a positive effect on the retention at flood by damping the flood wave and attenuating its peak. The damping rate is defined as the ratio between the outflow (Qo) and inflow hydrographs (Qi) peaks (Figure 1).

Numerical solutions of the equations of continuity and momentum are usually applied to investigate the spread of flooding in a reservoir and assess its effect on attenuation of the peak of the flood (GARCIA-NAVARRO; ZORRAQUINO, 1993).

However, often the intention is merely to verify expeditiously if the values found for the flood damping in a given project, are within the range of reasonableness for a given reservoir, with certain characteristics.

In this sense, are found in the literature some studies focusing on the expeditious scaling of small reservoirs, in urban areas. Horn (1987), for example, has proposed a procedure for the determination of the effluent flow as a function of the affluent hydrograph, reservoir storage and pouring structure, enabling a rapid assessment of the effects of changes of these parameters in flood mitigation.

Akan (1989) developed a method for the design of detention reservoirs of double outlet (spillway and hole) through the numerical evaluation of dimensionless equations, resulting in many abacuses for various return periods. Akan (1990) proposed dimensionless abacuses for analysis or design of detention reservoirs and spillways, according to different initial conditions. Akan and Antoun (1994) also developed dimensionless graphics for preliminary sizing of flood control basins, whereas only one output (hole or spillway), to the storable volume estimates.

Basha (1994), also working with urban basins, presented an analytical solution for simplified design of circular galleries and detention reservoirs, having the affluent hydrograph and parameters of the reservoir. Hong (2008) presented dimensionless abacuses for the calculation of the maximum volume of detention reservoirs for rain, based on their shape, in the spillway type and affluent hydrograph (triangular). Other graphics methods for design of

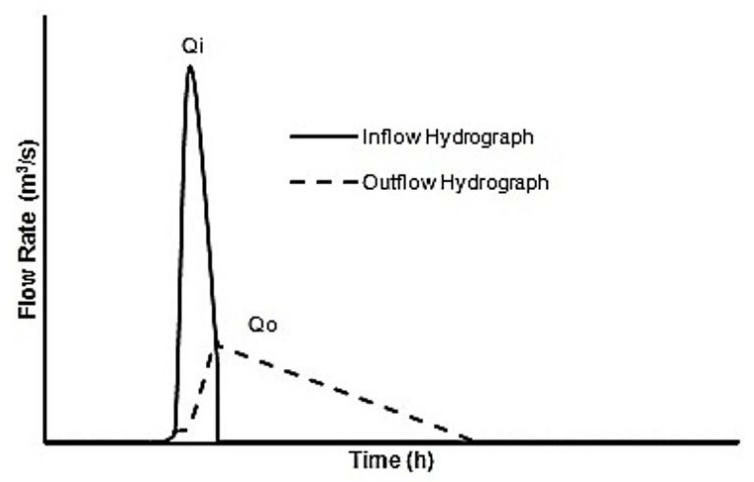

Figure 1. Inflow (Qi) and Outflow (Qo) hydrographs in a reservoir. 
detention basins, obtained through generalized numerical solution, are presented by Graber (2009) and Froehlich (2009). In all cases, simplifying assumptions are made for the storms and river basins. As a result, these models are more applicable to urban hydrology and small watersheds (SORDO-WARD et al., 2012).

Sordo-Ward et al. (2012) studied the abatement effect of large dams with fixed-crest spillways under extreme design flood conditions. An automated tool was designed for calculations based on a Monte Carlo simulation environment, which integrates models that represent the different physical processes in watersheds with areas of $150-2000 \mathrm{~km}^{2}$. The tool was applied to 21 sites that were uniformly distributed throughout continental Spain, with 105 fixed-crest dam configurations. For all cases studied, the authors obtained a strong linear correlation between the peak flow entering the reservoir and the peak flow discharged by the dam, and a simple general procedure was proposed to characterize the peak-flow attenuation behavior of the reservoir. Additionally, two dimensionless coefficients were defined by Sordo-Ward et al. (2013) to relate the variables governing both the generation of the flood and its abatement in the reservoir. Using these coefficients, a model was defined to allow for the estimation of the flood abatement effect of a reservoir. The method can be used to design reservoirs, as well as to dam safety assessment under the hydrological point of view.

\section{MATERIAL AND METHODS}

The methodology adopted in this paper, to describe the patterns and to estimate the affluent flood damping is hydrological simulation. The water level of the reservoir is considered at the spillway height, which corresponds to the worst situation for damping. Without extra volume to allocate the affluent flood, it spreads on lake surface and has its way out through the spillway

\section{Data used}

Since the 1990s, 79 reservoirs have been built in the state of Ceará. From these, it was selected for this study 19 reservoirs, depending on the availability of its original project, to identify the values of its parameters. The choice of the year 1990 to start the research is because, from then on, the "Safety Dam Board in Ceará" was installed, which standardized the projects in the State, adopting more modern methodologies.

\section{Hydrological simulation of reservoirs}

For the hydrological simulations, the HEC-HMS software (USACE, 2016) was used. In the loss and transformation processes, the Curve Number methods (D'ASARO et al., 2014; MAHMOUD, 2014) and the SCS unit hydrograph were used (BLAIR et al., 2014). The propagation in the reservoir was determined by the classical Puls Method.

\section{Design storm}

Because it is an expeditious method, it is necessary to make simplifying assumptions. Therefore, it was assumed that the whole State of Ceará features the same storm pattern observed in the João Guerra reservoir. All the reservoirs were simulated with linear hyetograph, with a total of $113 \mathrm{~mm}$ and rain duration equal to 6 hours, characteristics of the design storm of this reservoir.

To evaluate the influence of precipitation (shape, duration and magnitude) in the process of mitigation of flood hydrographs, reservoirs were also simulated with an empirical hyetograph, with rainfall duration equal to 6,12 and 24 hours and magnitudes following fractions of $\mathrm{P}(0.6 \mathrm{P}$ to $1.8 \mathrm{P})$, where $\mathrm{P}=113 \mathrm{~mm}$ (Table 1).

\section{Damping intervening parameters}

The damping rate (A) is a function of hydrological and morphological parameters of the watershed and reservoir. The parameters of the reservoir are the form factor (defines if the reservoir is more 'open' or 'closed'), the spillway height and the spillway width. The parameters of the basin are the area, the Curve Number (average value of the $\mathrm{CN}$ of the soils of the basin) and the time of concentration of the watershed contributing to the section of the reservoir.

Thus, the reservoir damping can be defined by Equation 1 .

$$
A=f(\alpha, B, C N, H, W, t c)
$$

Where: A denotes the damping rate, $\alpha$ is the reservoir shape factor; $\mathrm{B}$ represents the area of the watershed; $\mathrm{CN}$ is the value of the "curve number"; $\mathrm{H}$ is height of the spillway; $\mathrm{W}$ is width of the spillway and $t_{c}$ is time of concentration of the watershed.

The form factor $\alpha$ is determined by the model of the inverted cone (CAMPOS et al., 2016):

$$
\mathrm{V}=\alpha \cdot \mathrm{H}^{3}
$$

Where: $\mathrm{V}$ the storage capacity of the reservoir $\left(\mathrm{m}^{3}\right)$.

Table 2 presents the 19 reservoirs analyzed with their characteristics - reservoir form factor $(\alpha)$, spillway height $(\mathrm{H})$ and spillway width (W) - as well as those of their respective hydrographic basins - basin area (B), Curve Number (CN) and time of concentration $\left(\mathrm{t}_{\mathrm{c}}\right)$.

Table 1. Cumulative Rainfall Hyetographs (Empirical and Uniform).

\begin{tabular}{ccc}
\hline Interval & $\begin{array}{c}\text { Empirical } \\
(\mathbf{m m})\end{array}$ & $\begin{array}{c}\text { Uniform (Linear) } \\
(\mathbf{m m})\end{array}$ \\
\hline $5 \mathrm{~min}$ & 20.00 & 1.57 \\
$15 \mathrm{~min}$ & 37.00 & 4.71 \\
1h & 69.00 & 18.83 \\
2h & 83.00 & 37.67 \\
3h & 94.00 & 56.50 \\
6h & 113.00 & 113.00 \\
\hline
\end{tabular}


Table 2. Reservoirs and their catchment areas characteristics of the sample studied.

\begin{tabular}{|c|c|c|c|c|c|c|}
\hline \multirow{2}{*}{ Reservoir } & \multirow{2}{*}{$\begin{array}{l}\text { Reservoir shape } \\
\text { factor }(\alpha)\end{array}$} & \multirow{2}{*}{$\begin{array}{c}\text { Basin area } \\
\left(\mathrm{km}^{2}\right)\end{array}$} & \multirow{2}{*}{$\mathrm{CN}$} & \multicolumn{2}{|c|}{ Spillway } & \multirow{2}{*}{$\begin{array}{c}t_{c} \\
(\mathrm{~min})\end{array}$} \\
\hline & & & & Height $(\mathrm{H})(\mathrm{m})$ & Width (W) (m) & \\
\hline Carmina & $3,327.15$ & 189.30 & 82.00 & 16.00 & 100.00 & 229.20 \\
\hline Catu & $15,095.13$ & 64.50 & 65.00 & 13.00 & 30.00 & 420.00 \\
\hline Cauhipe & $15,446.18$ & 94.00 & 78.00 & 9.20 & 120.00 & 126.00 \\
\hline Flor do Campo & $23,726.23$ & 647.80 & 78.30 & 16.74 & 80.00 & 924.00 \\
\hline Gameleira & $12,802.00$ & 519.77 & 75.00 & 16.02 & 80.00 & 721.80 \\
\hline Gangorra & $13,546.60$ & 105.00 & 80.00 & 15.04 & 40.00 & 357.00 \\
\hline Itaúna & $38,974.38$ & 771.30 & 65.00 & 12.57 & 60.00 & 693.60 \\
\hline Jatobá & $1,386.73$ & 41.38 & 86.02 & 16.29 & 30.00 & 66.00 \\
\hline Jenipapeiro & $12,943.50$ & 186.40 & 80.00 & 14.97 & 75.00 & 243.00 \\
\hline Jerimum & $2,923.88$ & 386.00 & 79.60 & 19.14 & 80.00 & 570.00 \\
\hline João Guerra & $1,424.70$ & 134.00 & 80.00 & 17.54 & 100.00 & 282.00 \\
\hline Malcozinhado & $11,336.00$ & 240.00 & 65.00 & 14.94 & 60.00 & 798.00 \\
\hline Missi & $19,062.23$ & 652.60 & 80.00 & 15.09 & 150.00 & 636.00 \\
\hline Parambú & $1,462.62$ & 104.00 & 73.00 & 18.00 & 50.00 & 210.00 \\
\hline Riacho da Serra & $8,179.58$ & 173.40 & 82.00 & 14.21 & 120.00 & 456.00 \\
\hline Rosário & $7,218.01$ & 329.00 & 75.00 & 18.70 & 100.00 & 588.00 \\
\hline Sítios Novos & $22,492.97$ & 446.00 & 78.00 & 17.30 & 70.00 & 474.60 \\
\hline Ubaldinho & $9,422.22$ & 176.00 & 70.00 & 15.00 & 57.00 & 336.00 \\
\hline Umari & $11,632.74$ & 975.00 & 81.00 & 14.44 & 60.00 & 631.00 \\
\hline
\end{tabular}

Source: Ceará (2014).

\section{Simulated damping theoretical scenarios}

It was adopted in the simulations the same range of variation of the parameters found in the projects of the 19 reservoirs: reservoir shape factor (1,000 to 40,000), basin area (25 and 1,000 $\left.\mathrm{km}^{2}\right), \mathrm{CN}$ (60 to 90), width of the spillway (50 to $150 \mathrm{~m}$ ), height of the spillway (10.54 to $20.54 \mathrm{~m}$ ) and time of concentration (50 to $1,000 \mathrm{~min}$ ).

The adoption of different combinations of values for the intervening parameters $-\alpha, \mathrm{B}, \mathrm{CN}, \mathrm{H}, \mathrm{W}$ and $\mathrm{t}_{\mathrm{c}}-$ allowed to analyze the behavior of the damping process according to different configurations (theoretical scenarios) and to identify which of them present the greatest impact on the peak flow reduction.

\section{General equation of damping determination}

The aim was to establish a general equation for damping. To do so, all intervening parameters were aggregated into a dimensionless factor, called Damping Index $(\Phi)$.

The reservoir form factor $\alpha$ and $\mathrm{CN}$ are already dimensionless. Taking the other intervening variables, two other dimensionless parameters were determined: one relating physical characteristics of the reservoir to the hydrographic basin and the other one relating the forces of gravity with the forces of inertia of the flow in the basin. The first one was called the geometric parameter $(\gamma)$; the second, flow parameter $(\lambda)$.

Each theoretical scenario, with combinations of $\alpha, \mathrm{CN}$, $\gamma$ and $\lambda$ results in a value of $\Phi$, which, for its turn, results in a damping rate value (A).

Thus, a General Equation of Damping and a graphical method to estimate the value of the damping rate expeditiously, in function of $\Phi$, were formulated.

\section{General equation of damping validation}

For the method validation, seven other reservoirs built at different dates were selected (including Reservoir Cedro, the first large reservoir in the Northeast Brazil). The reservoirs and their watersheds characteristics are in Table 3.

The reservoirs were simulated, using the same design storm of $113 \mathrm{~mm}$, with duration of 6h, with linear hyetograph. The results of the simulations were compared with the results of the application of the General Equation of Damping.

\section{Comparison of 1,000 and 10,000-years return periods floods}

The same methodology was used for the calculation of 10,000-years return periods floods. The values were compared to identify if the General Equation of Damping can be used for both periods.

\section{RESULTS AND DISCUSSION}

The results of the simulations, considering different parameters involved, were divided into five groups:

- Analysis of the influences of the parameters involved in damping;

- General Equation of Damping adjustment, in function of the Damping Index $(\Phi)$;

- Construction and validation of a graphical method to estimate, in an expeditious way, the damping capacity; 
- Analysis of the influence of the shape of the hyetograph, the duration and the magnitude of the precipitation in the damping; and

- Application of the results to a real reservoir, including assessment of the impact of different interventions in the basin and in the reservoir.

\section{Understanding intervening parameters in damping}

The influence of the reservoir form factor, the area of the watershed, the $\mathrm{CN}$, the width and height of the spillway and the time of concentration in the damping of the floods were analyzed.

Influence of the reservoir shape factor $(\alpha)$ and the basin area (B)

Figure 2 presents the results of the joint action of reservoir shape factor (ranging from 1,000 to 40,000) and the basin area (ranging from 25 to $1,000 \mathrm{~km}^{2}$ ) in damping. It is observed in Figure 2a that, for a given value of the area, as the value of $\alpha$ increases (more open valleys), the reservoir increases the damping rate, since the affluent flood passes to have a larger hydraulic basin area for its spreading. It is also observed that the effect of the form factor on damping is more relevant in smaller basins $\left(25 \mathrm{~km}^{2}\right)$.

It is observed in Figure $2 b$ that, for a same value of $\alpha$, the damping decreases as the basin area increases. The decrease of damping with the area is faster in smaller basins $\left(\mathrm{B}<200 \mathrm{~km}^{2}\right)$ and in more closed valleys $(\alpha<1,500)$.

\section{Influence of reservoir shape factor $(\alpha)$ and the $\mathrm{CN}$ of the watershed}

It is observed in Figure 3 that the damping capacity decreases with the value of the $\mathrm{CN}$. Highest values of $\mathrm{CN}$ indicate greater impervious areas in the watershed, increasing the volume affluent to the reservoir and reducing its capacity to dampen such a flood. For high reservoir shape factor values $(\alpha>35,000)$, however, it has been found that the damping is almost $100 \%$, regardless of the $\mathrm{CN}$ value adopted.

Influence of the height of the spillway $(\mathrm{H})$ and the basin area $(\mathrm{B})$

It is observed in Figure 4 that the damping increases as the height of the spillway $(\mathrm{H})$ increases, given there is a greater accumulation capacity of the reservoir. There is, once again, the influence of the basin area (B); the effect of $\mathrm{H}$ is more relevant in smaller basins.

\section{Influence of spillway width (W) and basin area (B)}

Figure 5 shows that the damping decreases as the spillway width (W) increases.

Table 3. Reservoirs and their catchment areas characteristics used for the method validation.

\begin{tabular}{|c|c|c|c|c|c|c|}
\hline \multirow[b]{2}{*}{ Reservoir } & \multirow{2}{*}{$\begin{array}{c}\text { Reservoir } \\
\text { shape factor } \\
(\alpha)\end{array}$} & \multirow[b]{2}{*}{$\begin{array}{c}\text { Basin area } \\
\left(\mathrm{km}^{2}\right)\end{array}$} & \multirow[b]{2}{*}{$\mathrm{CN}$} & \multicolumn{2}{|c|}{ Spillway } & \multirow[b]{2}{*}{$\left(\begin{array}{c}t_{c} \\
(\mathrm{~min})\end{array}\right.$} \\
\hline & & & & $\begin{array}{l}\text { Height (H) } \\
\text { (m) }\end{array}$ & $\begin{array}{l}\text { Width (W) } \\
\text { (m) }\end{array}$ & \\
\hline Cedro & $20,822.1$ & 224.0 & 76.4 & 18.2 & 91.0 & 429.7 \\
\hline São José II & $4,327.5$ & 185.0 & 76.4 & 18.9 & 60.0 & 367.1 \\
\hline Tejuçuoca & $3,588.5$ & 180.0 & 76.4 & 19.9 & 60.0 & 358.7 \\
\hline Capitão Mor & 741.8 & 113.1 & 76.4 & 20.0 & 90.0 & 238.3 \\
\hline Pirabibu & $30,749.5$ & 520.0 & 76.4 & 13.4 & 180.0 & 735.8 \\
\hline P. Sobrinho (Choró) & $13,588.1$ & 322.0 & 76.4 & 21.9 & 50.0 & 564.0 \\
\hline São José I & $6,177.8$ & 15.5 & 76.4 & 10.7 & 120.0 & 35.2 \\
\hline
\end{tabular}

Source: Ceará (2014).

a)

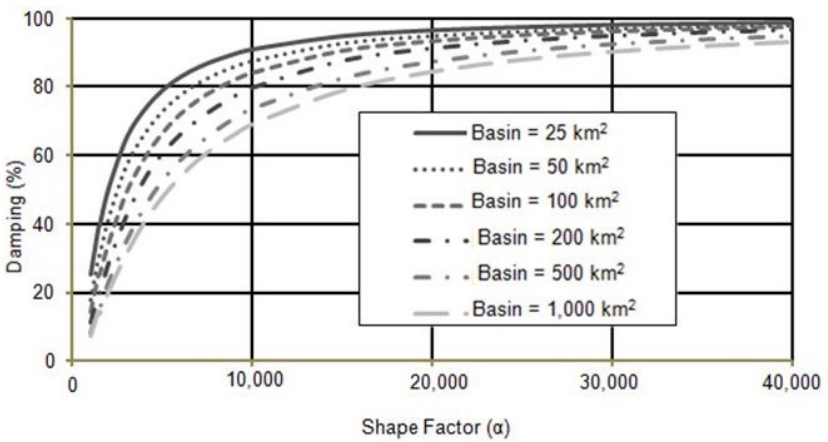

b)

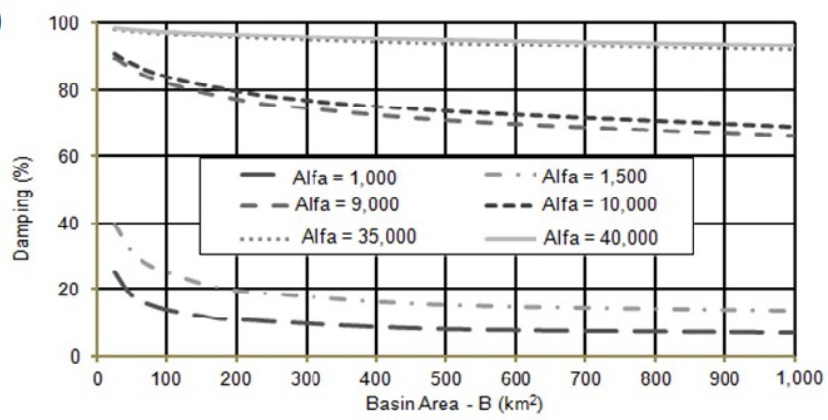

Figure 2. Joint impact of reservoir shape factor and basin area in damping: a) Impact of reservoir shape factor in damping with basin area varying between 25 and 1,000 $\mathrm{km}^{2}$; b) Impact of basin area in damping with reservoir shape factor varying between 1,000 and 40,000. 


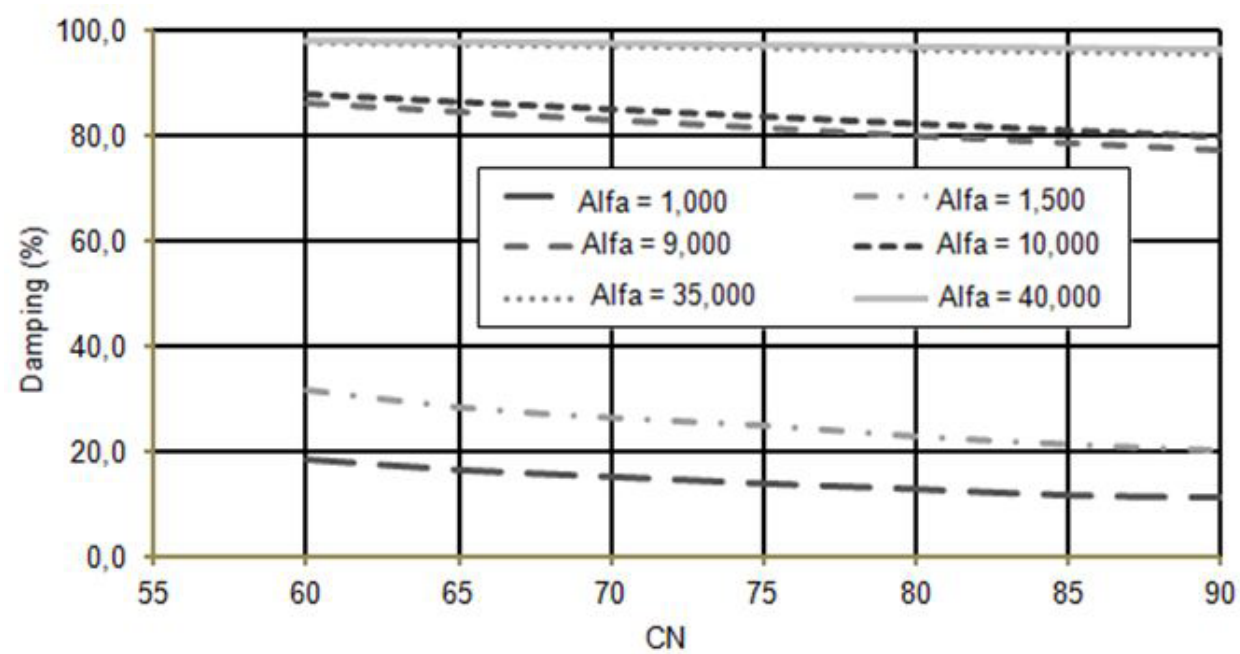

Figure 3. Impact of $\mathrm{CN}$ on damping with the reservoir shape factor $(\alpha)$ varying between 1,000 and 40,000.

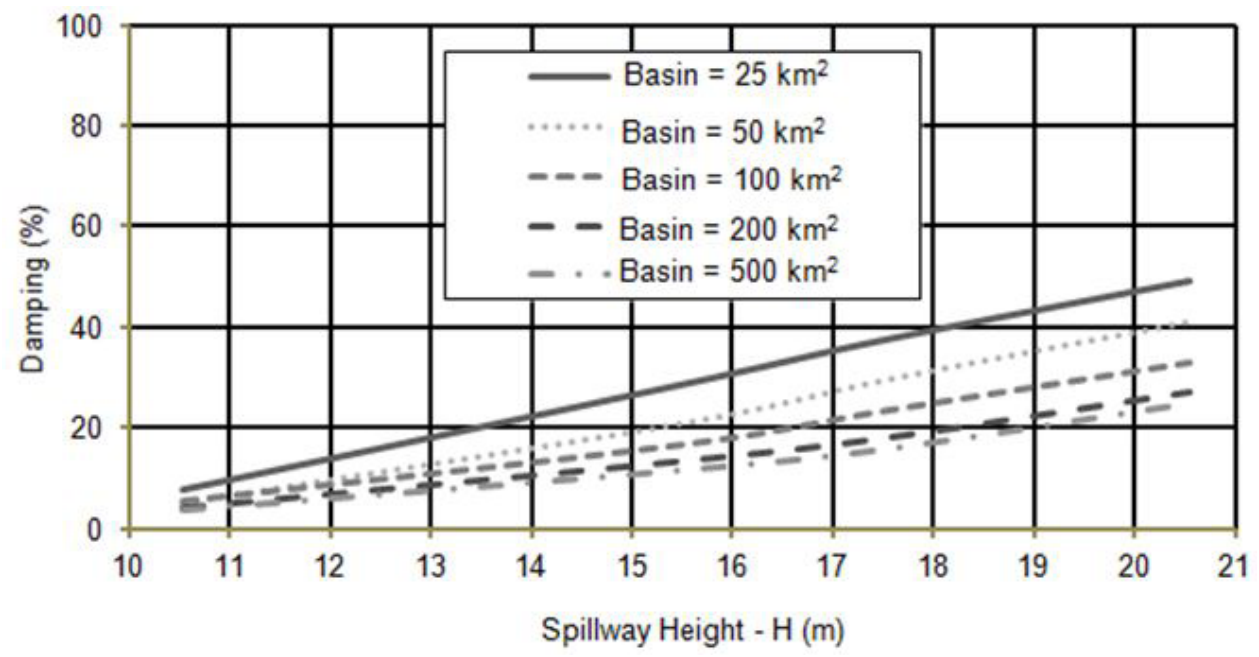

Figure 4. Impact of spillway height $(\mathrm{H})$ on damping with basin area (B) varying between 25 and 1,000 $\mathrm{km}^{2}$.

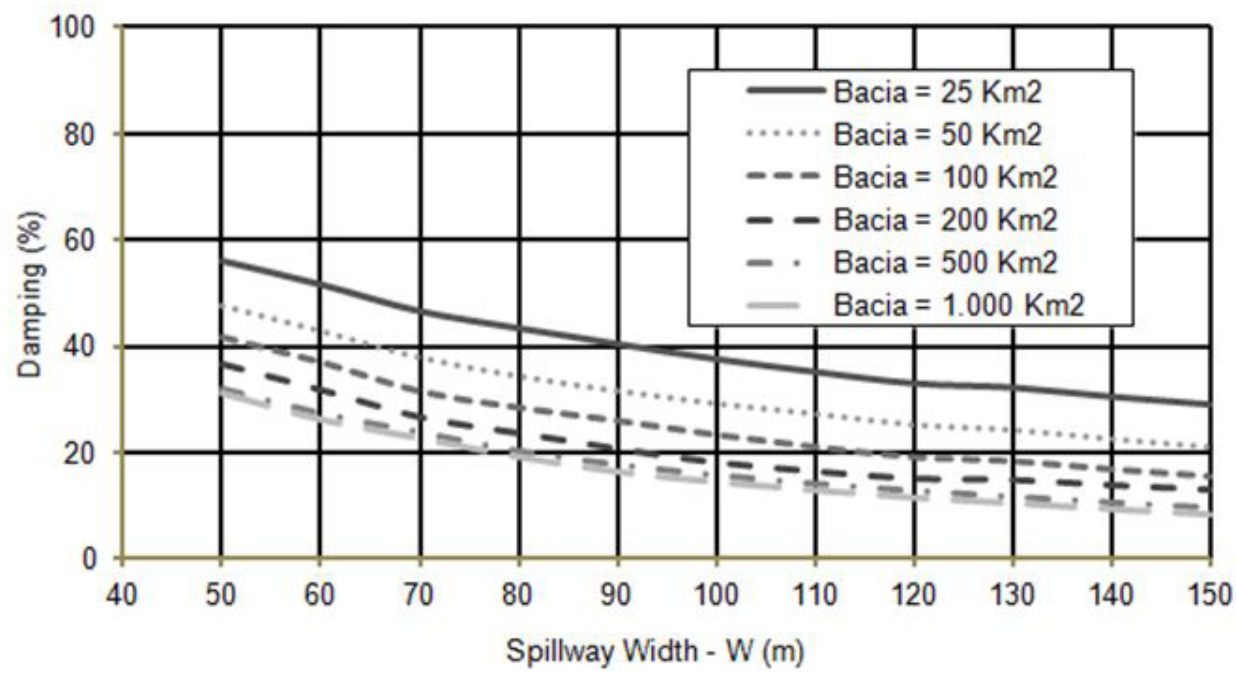

Figure 5. Impact of the spillway width (W) in damping with the basin area (B) varying between 25 and $1,000 \mathrm{~km}^{2}$. 
This is because the larger the spillway, the greater its discharge capacity (larger effluent flows) and the smaller the $Q_{0} / Q_{i}$ ratio. Once again, the effect of the basin area on the damping is noticed; the effect of $\mathrm{W}$ is more relevant in smaller basins.

\section{Influence of the time of concentration $\left(t_{c}\right)$}

Figure 6 shows the impact of the time of concentration on damping. It is observed that the damping decreases with the time of concentration. It was considered other parameters remaining constant $\left(\mathrm{B}=134.00 \mathrm{~km}^{2}, \mathrm{CN}=80, \mathrm{H}=17.54 \mathrm{~m}, \mathrm{~W}=100 \mathrm{~m}\right.$ and $\alpha=1,424.70)$.

It is observed in Figure 7 that smaller values of time of concentration (e.g. $200 \mathrm{~min}$ ) cause a rapid inflow of water into the reservoir, generating a considerable rise in water level (increasing the damping). However, higher values of time of concentration (e.g. $800 \mathrm{~min}$ ) cause a slower supply of water to the reservoir, resulting in a small change in the water level (reducing damping).

\section{General equation of damping}

A general equation of damping was determined, finding a dimensionless factor, called Damping Index $(\Phi)$ that aggregates all the other dimensionless parameters. Among the intervening parameters of $\mathrm{A}$, it is known that only $\alpha$ and $\mathrm{CN}$ are dimensionless. Thus, two new dimensionless parameters were defined: the geometric dimensionless $(\gamma)$, which reflects the physical characteristics of the reservoir to the hydrographic basin, and the flow parameter $(\lambda)$, which relates the forces of gravity with the forces of inertia of the flow in the basin

The determination of $\gamma$ was made after the analysis of the influence of $\mathrm{B}, \mathrm{H}$ and $\mathrm{W}$ on the damping rate $(\mathrm{A})$. It was verified that $\mathrm{A}$ increases with $\mathrm{H}$ and decreases with $\mathrm{W}$ and $\mathrm{B}$, following low-curvature curves. Thus, the geometric parameter $(\gamma)$ is described by Equation 3. It was found that the damping varies linearly with $\gamma$ (coefficient of determination $\left.r^{2}>0.90\right)$.

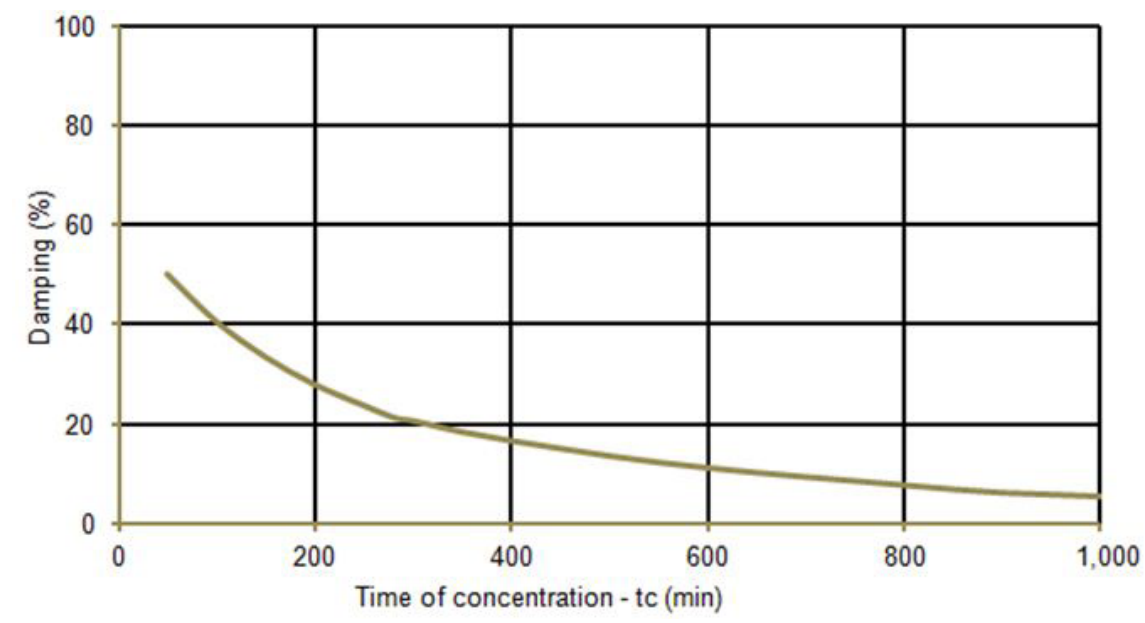

Figure 6. Impact of the time of concentration $\left(\mathrm{t}_{\mathrm{c}}\right)$ in damping.

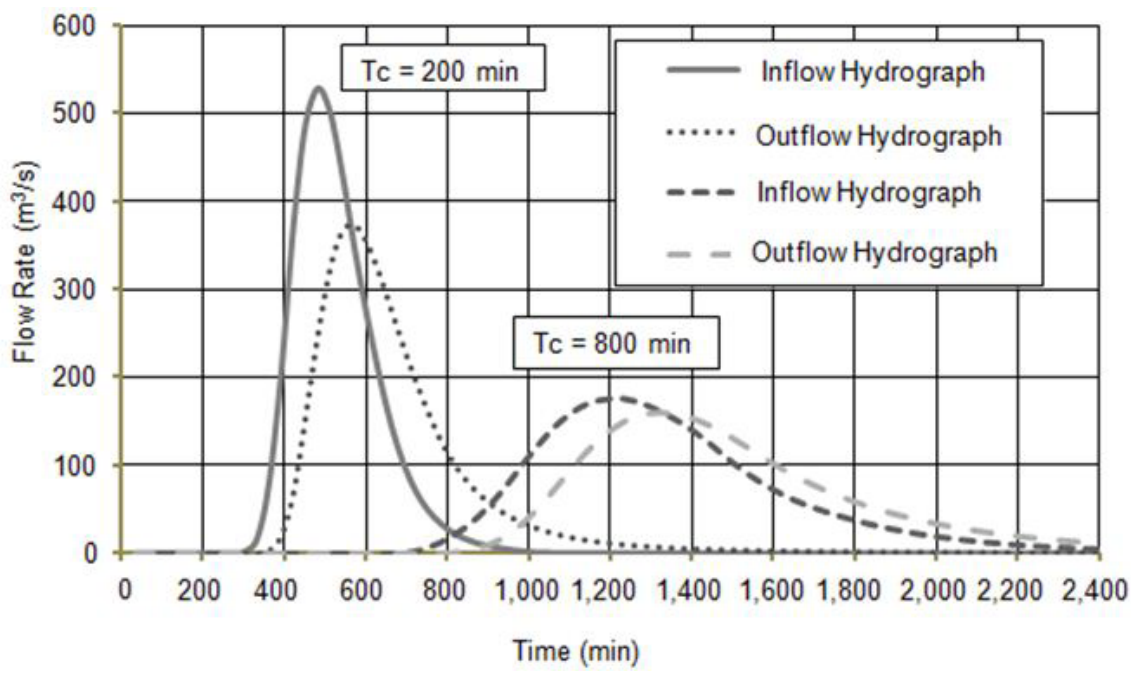

Figure 7. Simulation of the affluent and effluent hydrographs for different times of concentration. 
$\gamma=\mathrm{H}^{3} / \mathrm{W} \cdot \mathrm{B}$

The determination of $\lambda$ it was performed by combining time of concentration $\left(\mathrm{t}_{\mathrm{c}}\right)$, the basin area $(\mathrm{B})$ and the gravitational constant $(\mathrm{g})$. Considering that $\sqrt[2]{\mathrm{B}}$ and tc represent, respectively, a scale of length and a scale of time of the watershed, the Equation 4 can be interpreted as the inverse of the Froude Number, used to describe the free flows (rivers/ponds) through the dimensionless ratio between the forces of inertia and gravity.

$\lambda=\frac{\mathrm{g} \cdot \mathrm{Tc}^{2}}{\sqrt[2]{\mathrm{B}}}$

Therefore, the characteristics of the reservoir can be aggregated into a single dimensionless parameter called the Damping Index $(\Phi)$, described by the Equation 5 .

$\Phi=\left[\alpha^{\mathrm{a}} \cdot(1 / \mathrm{CN})^{\mathrm{b}} \gamma^{\mathrm{c}} \cdot \lambda^{\mathrm{d}}\right]$

Where: $\alpha$ is the reservoir shape factor, $\mathrm{CN}$ is the Curve Number of the reservoir basin; $\gamma$ is the dimensionless geometric parameter and $\lambda$ is the dimensionless flow parameter.

Equations 6 and 7 describe, respectively, the Damping Index $(\Phi)$ and the General Damping Equation (A), and were obtained by fitting the exponents a, b, c, as well as the coefficients of a fourth-degree polynomial that relates $A$ and $\Phi$, resulting in a coefficient of determination $\left(\mathrm{r}^{2}\right)$ equal to 0.93 .

$\Phi=\left[\alpha^{0,2} \cdot(1 / \mathrm{CN})^{0,3} \gamma^{0,09} \cdot \lambda^{-0,08}\right]$

$\mathrm{A}(\%)=756,1 . \Phi^{4}-509,9 . \Phi^{3}+119,0 . \Phi^{2}-10,5 . \Phi+304,1$

Figure 8 describes the equation of A. A greater dispersion is observed for values below 0.13 (low damping), which correspond to theoretical scenarios whose parameter combinations are atypical, such as very large basin areas and with small spillway width values.

The results obtained in the simulations were compared with those obtained by the General Equation of Damping (Figure 9). It was observed that most of the reservoirs (14) presented deviation of less than $10 \%$ between the simulated value and the value estimated by the equation, four presented a deviation less than $20 \%$ and only one reservoir (Macacos) presented deviation greater than $20 \%$.

\section{Damping of 1,000 and 10,000 years return period floods}

All calculations were performed for floods with return periods $\operatorname{Tr}=1,000$ years and $\operatorname{Tr}=10,000$ years. It was observed, however, that for the boundary conditions assumed in the present study, the results were very close to each other, with differences less than 10\%. Therefore, the General Equation of Damping (equation and graph) can be used to estimate the damping of the both return period floods.

\section{Graphical method validation}

To validate the General Equation of Damping, seven other reservoirs, constructed in different periods of the sample, were simulated.

Table 4 presents the results of the damping. Three reservoirs have parameters within the range of variation used for the construction of the equation; the other four have a parameter outside this range: Capitão Mor $(\alpha$ below minimum and $\mathrm{H}$ above maximum), Pirabibu (W above maximum), Choró (H above maximum) and São José I (B and $t_{c}$ lower than minimum).

It is also observed in Table 4 and Figure 10 that, once again, the results of the simulations and the General Equation of Damping are very close to each other, with deviations between the damping values estimated by simulation and general equation less than $14 \%$, which highlights the applicability of the method.

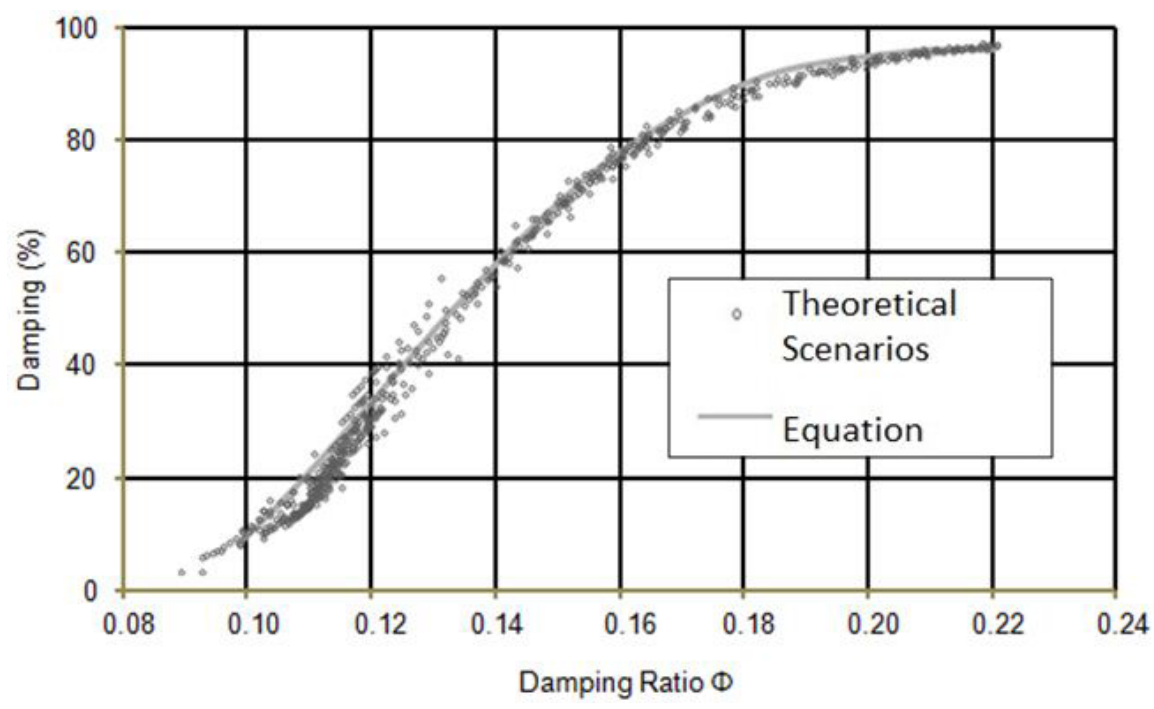

Figure 8. General Equation of Damping. 


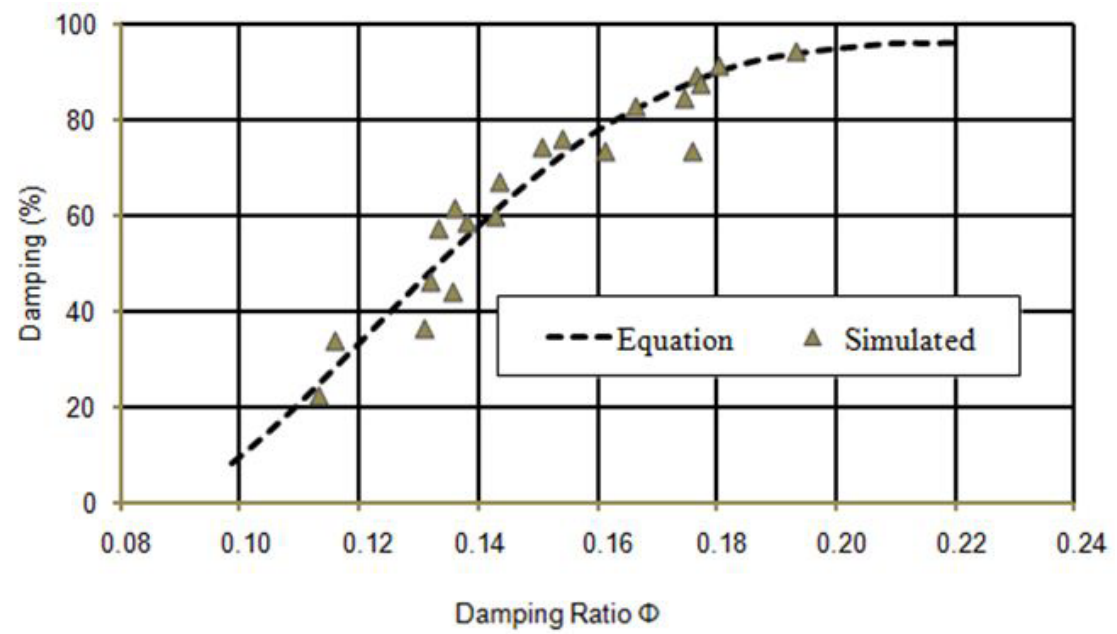

Figure 9. Comparative analysis of damping values calculated by simulation (HEC-HMS) and those estimated by General Equation of Damping (Equation 7).

Table 4. Reservoirs used for of the General Equation of Damping validation (Equation 7) and the deviations between simulation and equation.

\begin{tabular}{|c|c|c|c|c|}
\hline Reservoir & Simulation $(\%)$ & $\Phi$ & Equation (\%) & Deviation $(\%)$ \\
\hline \multicolumn{5}{|c|}{ Within the range of Simulated Scenarios } \\
\hline Cedro & 90.7 & 0.1819 & 90.6 & -0.1 \\
\hline São José II & 69.5 & 0.1442 & 62.4 & -11.2 \\
\hline Tejuçuoca & 67.6 & 0.1415 & 59.5 & -13.6 \\
\hline \multicolumn{5}{|c|}{ Out of range of the Simulated Scenarios } \\
\hline Capitão Mor & 17.2 & 0.1091 & 19.8 & 13.3 \\
\hline Pirabibu & 65.0 & 0.1498 & 68.2 & 4.6 \\
\hline P. Sobrinho (Choró) & 91.7 & 0.1742 & 87.1 & -5.3 \\
\hline São José I & 82.4 & 0.2058 & 95.4 & 13.6 \\
\hline
\end{tabular}

Source: Secretaria dos Recursos Hídricos (2014).

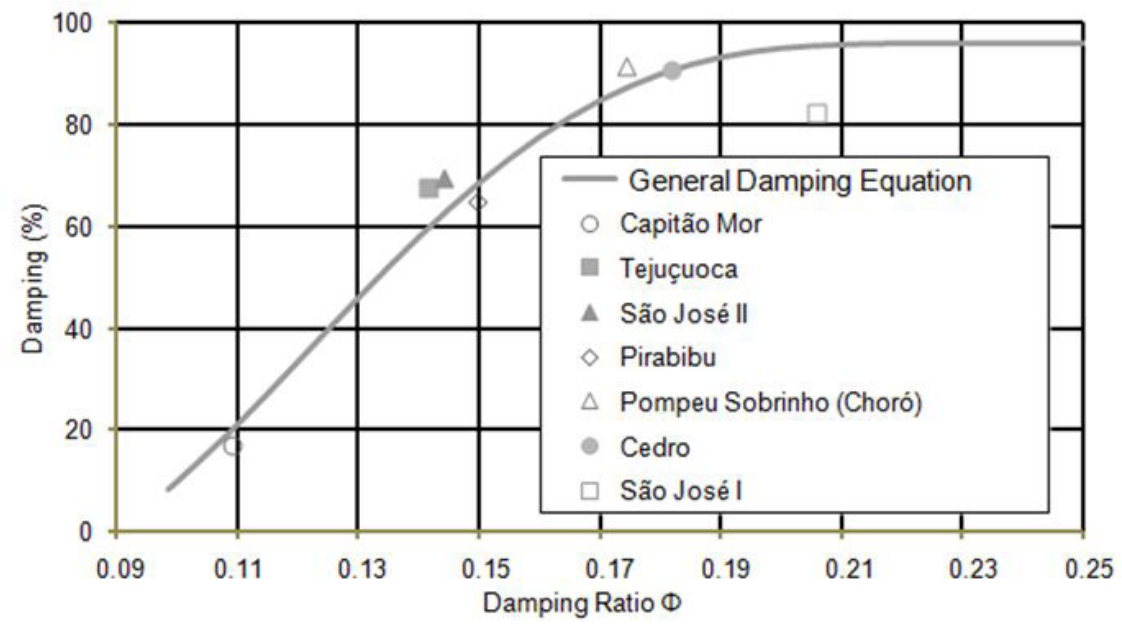

Figure 10. Graphical representation of the General Equation of Damping (Equation 7) and of the results of the simulations of reservoirs by the HEC-HMS.

\section{Influence of the shape of the hyetograph}

The influence of the shape of the hyetograph at peak flow of the affluent hydrograph was studied by Figueiredo and Campos (2007). The authors concluded that the larger the slope of the curve of the hyetograph, the greater the intensity of rain and, therefore, higher peak flow. Alfieri, Laio and Claps (2008) also evaluated the impact of the use of synthetic hyetographs in the estimation of peak flows during flood events, concluding that all present a bias in the estimates of the peak of the hydrograph 
in most climatic and hydrological conditions. The rectangular hyetograph underestimates the peak flows of the Rational Method and the hyetograph by the Chicago Method overestimates them.

In this study, the influence of the shape of the hyetograph on the dampening rate of floods was studied with hydrologic simulation of 19 reservoirs by applying the uniform hyetograph (linear) and an empirical hyetograph, with the same duration (6h) magnitude of rain ( $\mathrm{P}=113 \mathrm{~mm}$ ), described in the Methodology.

The results showed that, on average, the damping corresponding to the uniform rainfall is $5 \%$ lower than the damping value using empirical hyetograph. Therefore, in terms of damping, the impact of the shape of hyetograph is not significant. Somehow, the spreading of the water on the surface of the lake, performs an aggregation of the affluent volumes and reduces the effects of the temporal distribution.

\section{Influence of duration and magnitude of design storm}

The simulations were made with variation of the duration and magnitude of the maximum rainfall. Rainfall durations of $6 \mathrm{~h}$, $12 \mathrm{~h}$ and $24 \mathrm{~h}$ were adopted and magnitudes varying from 0.6 to 1.8.P (where $\mathrm{P}=113 \mathrm{~mm}$ ). It is observed in Table 5 that the duration of the precipitation has a very small influence on the value of the damping; for the same rainfall value, the deviations in damping values for different durations are less than $10 \%$.
Because it is expeditious review or verification of values previously calculated by different methods, one can therefore adopt 24-hour rainfall obtained directly from the statistical adjustment of the rain gage data, since the duration does not have a significant impact on the damping. On the other hand, for a given rain duration, a reduction in damping is observed as the magnitude of the rainfall increases, since there is an increase in the inflow (Figure 11).

Table 6 shows correction of damping coefficients for each fraction of rain. For a design rainfall equal to 0.6 , the correction coefficient shall be 1.1384; to 0.7 , will be of 1.0926 , and so on until 1.8. $\mathrm{P}$, where $\mathrm{P}$ is the reference rainfall, equal to $113 \mathrm{~mm}$.

\section{Application: the case study of Reservoir Malcozinhado}

The General Damping Equation was applied to evaluate the damping level of the Reservoir Malcozinhado flood, whose parameters can be found in Table 7 .

Based on the basin and reservoir characteristics, the dimensionless geometric parameter $(\gamma)$ and dimensionless flow parameter $(\lambda)$ are calculated and then the Damping Index $(\Phi=0.1503)$ is determined .

The graphical determination of the damping is done by drawing a vertical line from the $\mathrm{x}$-axis $(\Phi)$ to the graph (Figure 12). From the given point, a horizontal line is drawn to the $y$-axis and the damping $(\mathrm{A} \%)$ is found.

Table 5. Impact of change in design storm (duration and magnitude) in damping.

\begin{tabular}{|c|c|c|c|c|c|}
\hline \multirow{2}{*}{$\begin{array}{l}\text { Fraction of Rain } \\
\qquad(P=113 \mathrm{~mm})\end{array}$} & \multicolumn{3}{|c|}{ Duration of Rain } & \multicolumn{2}{|c|}{$\begin{array}{l}\text { Deviations from the calculated } \\
\text { damping for duration equal to } 6 \mathrm{~h}\end{array}$} \\
\hline & $6 h$ & $12 \mathrm{~h}$ & $24 \mathrm{~h}$ & $\begin{array}{l}\text { Deviation }(\%) \\
12 \mathrm{~h} / 6 \mathrm{~h}\end{array}$ & $\begin{array}{c}\text { Deviation }(\%) \\
12 \mathrm{~h} / 6 \mathrm{~h}\end{array}$ \\
\hline 0.6 & 30.23 & 29.62 & 29.79 & -2.00 & -1.44 \\
\hline 1.0 & 22.53 & 22.43 & 21.94 & -0.43 & -2.62 \\
\hline 1.4 & 19.15 & 18.81 & 17.68 & -1.79 & -7.68 \\
\hline 1.8 & 17.63 & 17.43 & 16.43 & -1.13 & -6.82 \\
\hline
\end{tabular}

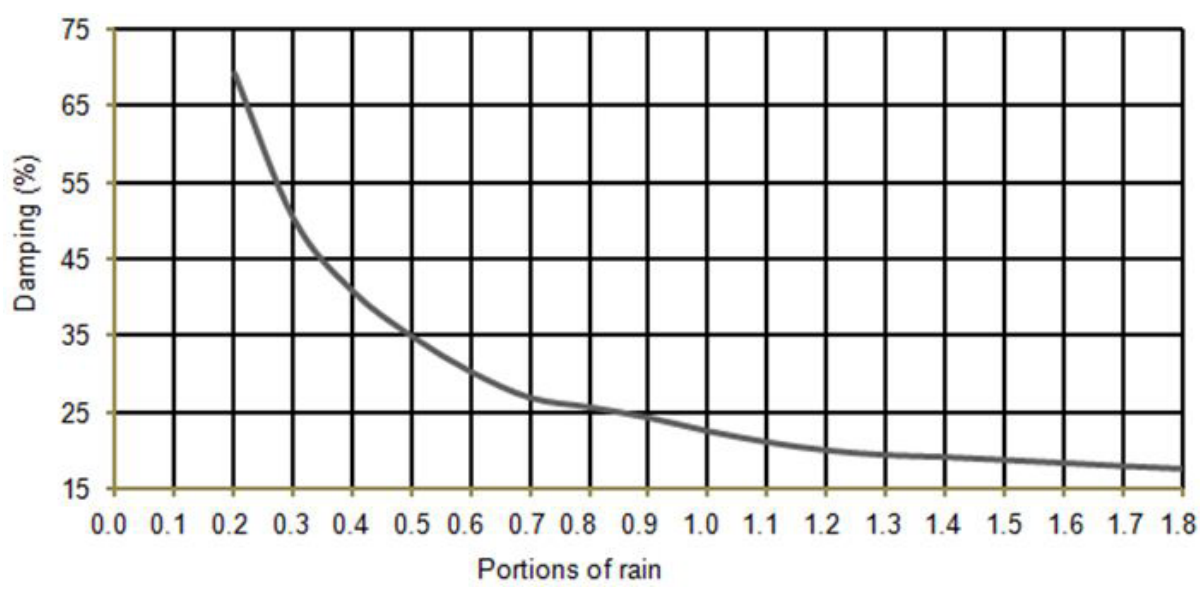

Figure 11. Impact of the magnitude of rainfall in damping. 
Table 6. Damping correction coefficients for each fraction of reference rain $(113 \mathrm{~mm})$.

\begin{tabular}{cccc}
\hline $\begin{array}{c}\text { Fraction } \\
\text { of } \\
\text { Rain }\end{array}$ & Coefficient & $\begin{array}{c}\text { Fraction of } \\
\text { Rain }\end{array}$ & Coefficient \\
\hline 0.6 & 1.1384 & 1.3 & 0.9416 \\
0.7 & 1.0926 & 1.4 & 0.9300 \\
0.8 & 1.0581 & 1.5 & 0.9170 \\
0.9 & 1.0275 & 1.6 & 0.9053 \\
1.0 & 1.0000 & 1.7 & 0.8966 \\
1.1 & 0.9773 & 1.8 & 0.8840 \\
1.2 & 0.9575 & - & - \\
\hline
\end{tabular}

Table 7. Reservoir Malcozinhado: current situation.

\begin{tabular}{cc}
\hline Parameters & Reservoir Malcozinhado \\
\hline Reservoir shape factor $(\alpha)$ & $11,336.00$ \\
Basin area $\left(\mathrm{km}^{2}\right)$ & 240.00 \\
CN & 65.00 \\
Spillway Width $(\mathrm{m})$ & 60.00 \\
Spillway Height $(\mathrm{m})$ & 14.94 \\
$\mathrm{t}_{\mathrm{c}}$ (min) & 798.00 \\
$\Phi$ & 0.1503 \\
\hline
\end{tabular}

Changes in the basin and in the reservoir

It is also possible to evaluate the damping in different scenarios, such as urbanization of the basin (alteration of the $\mathrm{CN}$ ), sedimentation of the reservoir (alteration of $\alpha$ ) or increase of the width of the spillway (W change).

Table 8 shows an example of new scenarios for the basin-reservoir system and its impacts on damping. It is observed that in Reservoir Malcozinhado current situation $(\Phi=0.1503)$, the estimated damping is around $70 \%$. Assuming an increase in the urbanization of the basin, with $\mathrm{CN}$ increasing from 65 to 80 ( $\Phi=0.1412)$, the damping capacity reduces to about $60 \%$. In a joint urbanization scenario $(\mathrm{CN}=80)$ and reservoir sedimentation, with $\alpha$ being reduced to $7,500(\Phi=0.1300)$, the damping is further reduced to $46 \%$ (Figure 13).

In the scenario related to the increase of the spillway width from 60 to 130 meters $(\Phi=0.1402)$, the estimated damping value is $60 \%$ (Figure 14). In this case, it is observed that by doubling the width of the spillway, the impact on the damping is like the increase of $\mathrm{CN}$ from 65 to 80 , resulting from the urbanization of the basin.

It is also possible to evaluate a scenario of climatic changes in Reservoir Malcozinhado, with its precipitation ranging from $\mathrm{P}$

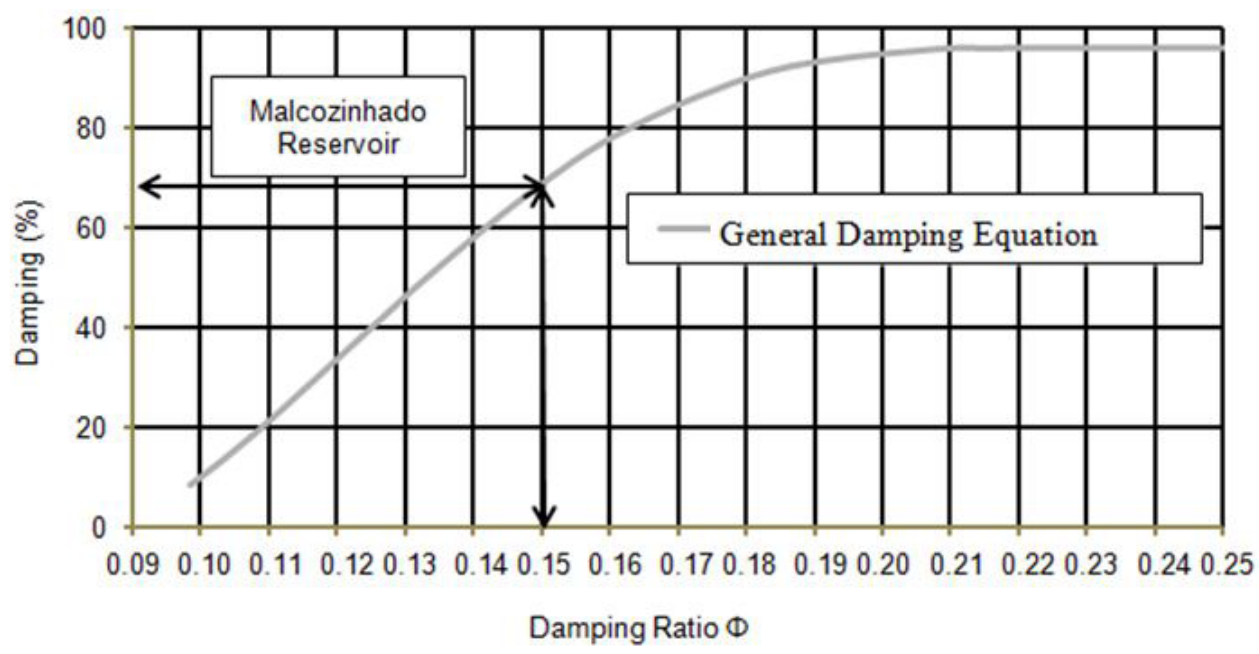

Figure 12. Utilization of the General Equation of Damping (Equation 7) in Reservoir Malcozinhado.

Table 8. Damping of Reservoir Malcozinhado: current situation and possible changes in the watershed and reservoir.

\begin{tabular}{|c|c|c|c|c|}
\hline \multirow[b]{2}{*}{ Parameters } & \multirow{2}{*}{$\begin{array}{l}\text { Current } \\
\text { Situation }\end{array}$} & \multicolumn{3}{|c|}{ Alternative Scenarios } \\
\hline & & Urbanization & Sedimentation & $\begin{array}{l}\text { Increased width of the } \\
\text { Spillway }\end{array}$ \\
\hline Reservoir shape factor $(\alpha)$ & $11,336.00$ & $11,336.00$ & $7,500.00$ & $11,336.00$ \\
\hline Basin area $\left(\mathrm{km}^{2}\right)$ & 240.00 & 240.00 & 240.00 & 240.00 \\
\hline $\mathrm{CN}$ & 65.00 & 80.00 & 80.00 & 65.00 \\
\hline Spillway Width (m) & 60.00 & 60.00 & 60.00 & 130.00 \\
\hline Spillway Height (m) & 14.94 & 14.94 & 14.94 & 14.94 \\
\hline tc $(\min )$ & 798.00 & 798.00 & 798.00 & 798.00 \\
\hline$\Phi$ & 0.1503 & 0.1412 & 0.1300 & 0.1402 \\
\hline Damping ratio (\%) & 68.7 & 59.1 & 45.8 & 57.9 \\
\hline
\end{tabular}




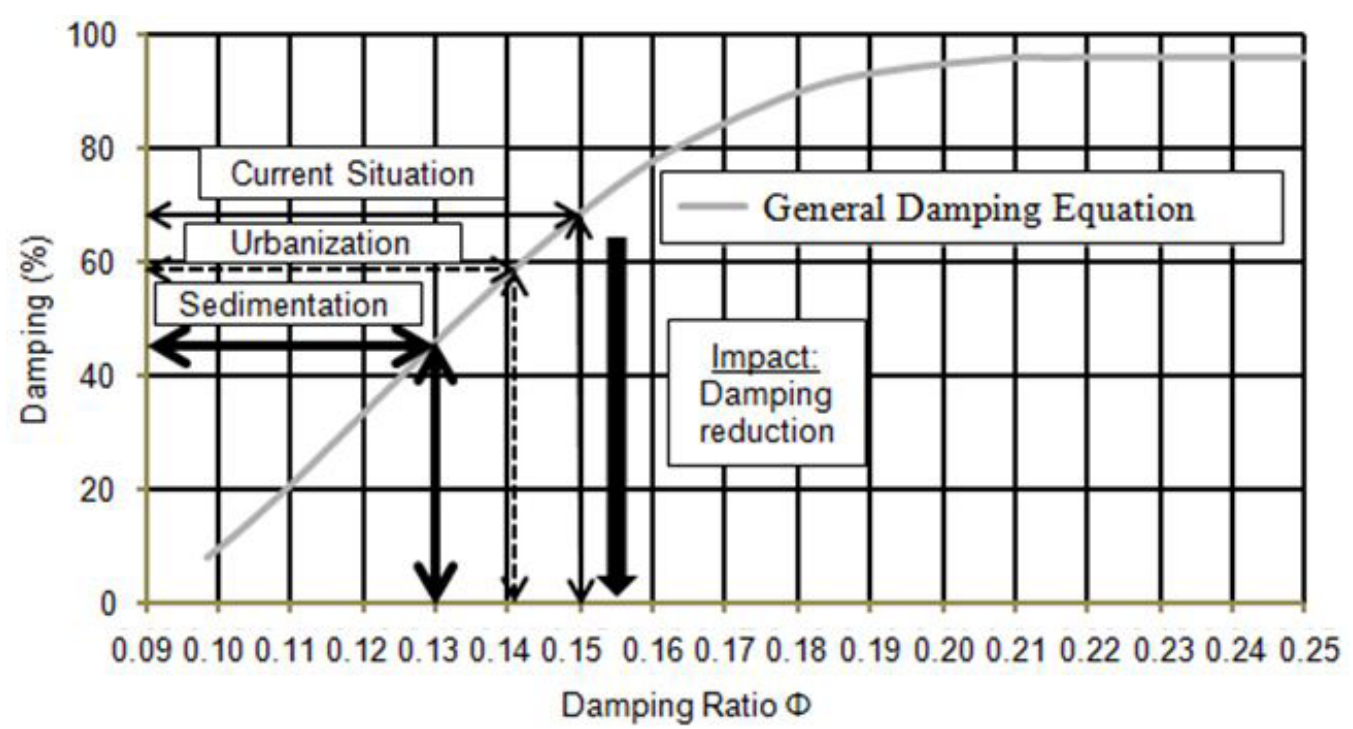

Figure 13. Application of General Equation of Dampin (Equation 7) - impacts of basin urbanization and lake sedimentation on damping capacity.

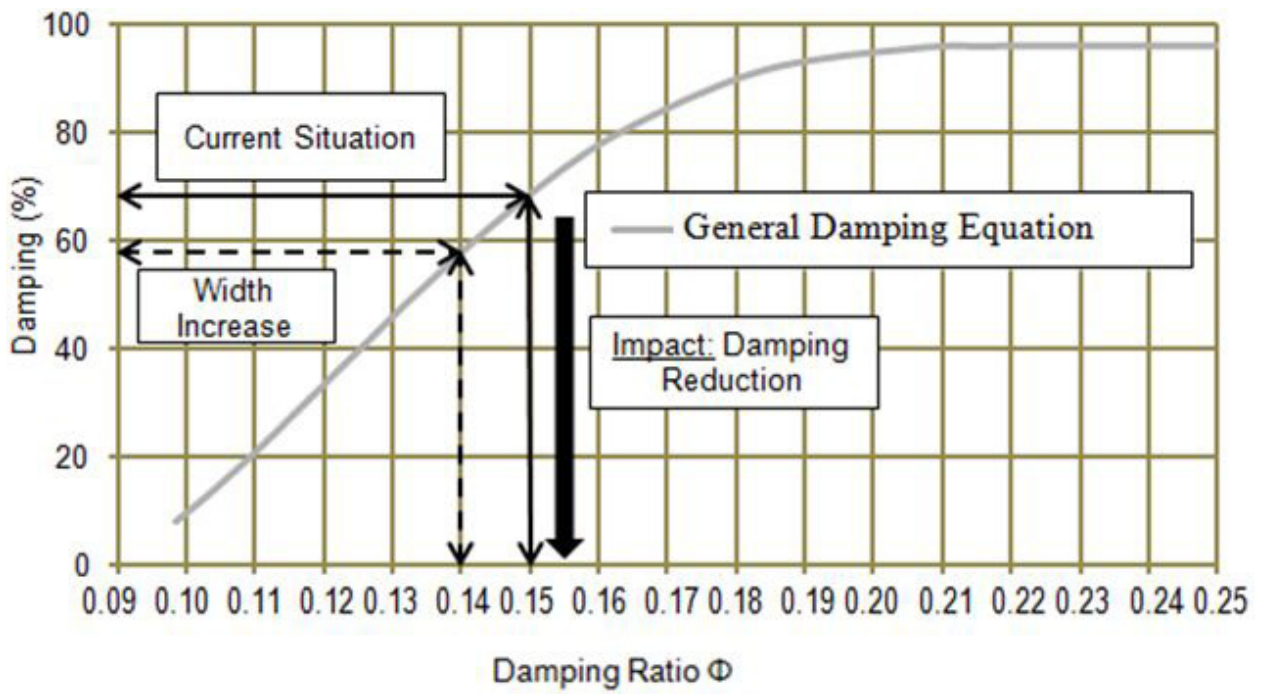

Figure 14. Impact of spillway width (W) increase on damping capacity.

(current) to 0.6.P. For $\Phi$ constant and equal to 0.1503 (Current Scenario), it is observed that the decrease of the precipitation magnitude increases the damping, which goes from $68.7 \%$ to $78.2 \%$ (damping correction coefficient for this fraction of rainfall on Table 6 is 1.1384).

\section{CONCLUSIONS}

In this study, hydrological simulations of several scenarios representative of reservoir configurations and hydrographic basins of the State of Ceará, Brazil, were carried out to evaluate reservoir damping.

The results indicated that damping increases with the reservoir shape factor and spillway height. On the other hand, it decreases with the hydrographic basin area, $\mathrm{CN}$ factor, spillway width and time of concentration.
The other methods for estimation of damping, cited in the literature, use inflow hydrographs as input data. The method proposed here uses morphological parameters of the basin and the reservoir, with the subsequent calculation of the Damping Index $\Phi$ and the correction of the magnitude of the precipitation.

Regarding the precipitation, it was observed that its duration has a reduced impact on the damping capacity of the reservoir, Thus, rainfall with a duration of 24 hours, obtained easily from rain gauges, can be used in this method. As for the shape of the hyetograph, although it is known that it affects the peak of the affluent hydrograph, it has little influence on the damping, so that the simple linear hietograph can be adopted.

The proposed method, called here the General Damping Equation, can be applied to 1,000 and 10,000 years return period floods, since the results were very similar. It also allows estimating alternative scenarios by calculating the impact of changes in the 
basin (urbanization) or in the reservoir (sedimentation of the lake or increasing the width of the spillway).

In summary, the General Equation of Damping presented very close results to those from HEC-HMSvsimulations, with deviations lower than $15 \%$. Additionally, this method is easy to apply and can be used as a tool for the analysis of the hydrological safety of reservoirs, either for the expedited estimation of the damping of reservoirs in the design phase, or for verifying spillways of existing reservoirs constructed according to other methodologies.

\section{REFERENCES}

AKAN, A. O. Detention pond sizing for multiple return periods. Journal of Hydraulic Engineering, v. 115, n. 5, p. 650-664, 1989. http:// dx.doi.org/10.1061/(ASCE)0733-9429(1989)115:5(650).

AKAN, A. O. Single-outlet detention-pond analysis and design. Journal of Irrigation and Drainage Engineering, v. 116, n. 4, p. 527-536, 1990. http://dx.doi.org/10.1061/(ASCE)0733-9437(1990)116:4(527).

AKAN, A. O.; ANTOUN, E. N. Runoff detention for flood volume or erosion control. Journal of Irrigation and Drainage Engineering, v. 120, n. 1, p. 168-178, 1994. http://dx.doi.org/10.1061/(ASCE)07339437(1994)120:1(168).

ALFIERI, L.; LAIO, F; CLAPS, P. A simulation experiment for optimal design hyetograph selection. Hydrological Processes, v. 22, n. 6, p. 813-820, 2008. http://dx.doi.org/10.1002/hyp.6646.

ANA - AGÊNCIA NACIONAL DE ÁGUA. Relatório de Segurança de Barragens 2015. Brasília, 2016. Available from: <http:// www2.ana.gov.br/Paginas/servicos/cadastros/Barragens/ RelatoriodeSegurancadeBarragens.aspx>. Access on: 7 feb. 2017.

BASHA, H. A. Nonlinear reservoir routing: particular analytical solution. Journal of Hydraulic Engineering, v. 120, n. 5, 1994. http:/ / dx.doi.org/10.1061/(ASCE)0733-9429(1994)120:5(624).

BLAIR, A.; SANGER, D.; WHITE, D.; HOLLAND, A. F; VANDIVER, L.; BOWKER, C.; WHITE, S. Quantifying and simulating storm water runoff in watersheds. Hydrological Processes, v. 28, n. 3, p. 559-569, 2014. http://dx.doi.org/10.1002/hyp.9616.

BRASIL. Lei no 12.334, de 20 de setembro de 2010. Estabelece a Política Nacional de Segurança de Barragens. Diário Oficial [da] República Federativa do Brasil, Brasília, DF, 20 set. 2010. Available from: <http://www.planalto.gov.br/ccivil_03/_Ato2007-2010/2010/ Lei/L12334.htm>. Access on: 13 Nov. 2014.

BRASIL. Ministério da Integração Nacional. A segurança de barragens e a gestão de Recursos Hídricos no Brasil. Brasília: Proágua, 2005.

BRASIL. Projeto de Lei no 224/ 2016. Altera a Lei no 12.334, de 20 de setembro de 2010. Diário Oficial [da] República Federativa do Brasil, Brasília, DF, 2016. Available from: <http://www25.senado. leg.br/web/atividade/materias/-/materia/125966>. Access on: 10 feb. 2017.
CAMPOS, J.; STUDART, T. M.C. Drought and water policies in Northeast Brazil: backgrounds and rationale. Water Policy, v. 10, n. 5, p. 425-438, 2008. http://dx.doi.org/10.2166/wp.2008.058.

CAMPOS, J.N.B; LIMA NETO, I.E.; STUDART, T.M.C.; NASCIMENTO, L.S. Trade-off between reservoir yield and evaporation losses as a function of lake morphology in semi-arid Brazil. Annals of the Brazilian Academy of Sciences, v. 88, n. 2, p. 11131125, 2016. http://dx.doi.org/10.1590/0001-3765201620150124.

CEARÁ. Governo do Estado. Secretaria dos Recursos Hídricos. Ceará, 2014. Available from: <http://www.ged.srh.ce.gov.br>. Access on: 4 mar. 2014.

D'ASARO, F.; GRILLONE, G.; HAWKINS, R. Curve number: empirical evaluation and comparison with Curve Number Handbook Tables in sicily. Journal of Hydrologic Engineering, v. 19, n. 12, 2014. Available from: < http://ascelibrary.org/doi/abs/10.1061/(ASCE) HE.1943-5584.0000997\#sthash.C3dKRGM6.dpuf>. Access on: 08 mar. 2017.

FIGUEIREDO, N. N.; CAMPOS, J. N. B. O efeito do hietograma na vazão de pico de cheias. In: SIMPÓSIO BRASILEIRO DE RECURSOS HÍDRICOS, 17., 2007, São Paulo. Anais... Porto Alegre: ABRH, 2007.

FROEHLICH, D. C. Graphical sizing of small single-outlet detention basins in the semiarid southwest. Journal of Irrigation and Drainage Engineering, v. 135, n. 6, p. 779-790, 2009. http://dx.doi. org/10.1061/(ASCE)IR.1943-4774.0000108.

GARCIA-NAVARRO, P.; ZORRAQUINO, V. Numerical modeling of flood propagation through system of reservoirs. Journal of Hydraulic Engineering, v. 119, n. 3, p. 380-389, 1993. http://dx.doi. org/10.1061/(ASCE)0733-9429(1993)119:3(380).

GRABER, S. D. Generalized numerical solution for detention basin design. Journal of Irrigation and Drainage Engineering, v. 135, n. 4, p. 487-492, 2009. http://dx.doi.org/10.1061/(ASCE)IR.19434774.0000010.

HONG, Y. Graphical estimation of detention pond volume for rainfall of short duration. Journal of Hydro-environment Research, v. 2, n. 2, p. 109-117, 2008. http://dx.doi.org/10.1016/j.jher.2008.06.003.

HORN, D. R. Graphic estimation of peak flow reduction in reservoirs. Journal of Hydraulic Engineering, v. 113, n. 11, 1987. http://dx.doi.org/10.1061/(ASCE)0733-9429(1987)113:11(1441).

MAHMOUD, S. Investigation of rainfall-runoff modeling for Egypt by using remote sensing and GIS integration. Catena, v. 120, p. 111-112, 2014. Available from: < http://www.sciencedirect. com/science/article/pii/S034181621400109X>. Access on: 08 Mar. 2017.

SORDO-WARD, A.; GARROTE, L.; BEJARANO, M. D.; CASTILLO, L. Extreme flood abatement in large dams with 
gate-controlled spillways. Journal of Hydrology (Amsterdam), v. 498, p. 113-123, 2013. http://dx.doi.org/10.1016/j.jhydrol.2013.06.010.

SORDO-WARD, A.; GARROTE, L.; MARTÍN-CARRASCO, F.; BEJARANO, M. D. Extreme flood abatement in large dams with fixed-crest spillways. Journal of Hydrology (Amsterdam), v. 466-467, p. 60-72, 2012. http://dx.doi.org/10.1016/j.jhydrol.2012.08.009.

USACE - U.S. ARMY CORPS OF ENGINEERS. Hydrologic Modeling System: HEC-HMS user's manual. Davis, 2016. Available from: <http://www.hec.usace.army.mil/software/hec-hms/ documentation/HEC-HMS_Users_Manual_4.2.pdf $>$. Access on: 4 aug. 2016.

WANDERLEY, L. J.; MANSUR, M.S.; MILANEZ, B; PINTO, R.G. Desastre da Samarco/Vale/BHP no Vale do Rio Doce: aspectos econômicos, políticos e sócio ambientais. Ciência e Cultura, vol. 68, n. 3, p. 30-35, 2016. http://dx.doi.org/10.21800/231766602016000300011.

WANG, F.; ZHANG, L. Systemic estimation of dam overtopping probability: bayesian networks approach. Journal of Infrastructure Systems, v. 23, n. 2, p. 1-12, 2016. Available from: <https://www.
researchgate.net/profile/Fan_Wang44/publication/308415292_ Systemic_Estimation_of_Dam_Overtopping_Probability_Bayesian_ Networks_Approach/links/57e3b22508ae112d973bbc97.pdf>. Access in: 02 mar. 2017.

ZHANG, L.; PENG, M.; CHANG, D.; XU, Y. Dam failure: mechanisms and risk assessment. Singapore: John Wiley, 2016.

\section{Authors contributions}

Danilo Nogueira de Souza: Literature review, HEC-HMS simulations, model development and discussion of the results.

Ticiana Marinho de Carvalho Studart: Literature review, model development, discussion of the results, write the final paper.

José Nilson Beserra Campos: Model development, discussion of the results and write the final paper.

Iran Eduardo Lima Neto: Model development and simulations, and discussion of the results. 